\title{
Successional changes in plant composition over 15 years in a created wetland in South Korea
}

\author{
Deokjoo Son ${ }^{1}$, Hyohyemi Lee ${ }^{2}$, Kang-Hyun Cho ${ }^{3}$, Jeong Hwan Bang ${ }^{1}$, Oh-Byung Kwon ${ }^{4}$ and Eun Ju Lee ${ }^{1 *}$
}

\begin{abstract}
Backgrounds: The main purpose of this research was to assess changes in vegetation structure, wetland index, and diversity index for a 15-year-old created wetland in Jincheon, South Korea. The created wetland consists of four sub-wetlands: a kidney-shaped wetland, a ditch, an ecological pond, and a square wetland. Vegetation and water depth data were collected at each site in 1999 and 2013, and Shannon diversity and wetland indices were calculated.

Results: The total number of plant species increased from 18 in 1999 to 50 in 2013, and the ecological pond in 1999 and the ditch in 2013 presented the highest diversity indices (2.5 and 3.2, respectively). Plant species were less diverse in 1999 than in 2013, presumably because these initial wetlands were managed periodically for water purification and installation of test beds. The proportion of wetland plants, including obligate wetland and facultative wetland species, decreased from 83 to 56\%, whereas upland plants, including obligate upland and facultative upland species, increased from 17 to 44\%. After ceasing water supply, water depth in all four sub-wetlands declined in 2013. Thus, upland plants established more readily at these sites, resulting in higher diversity and lower wetland indices than in 1999.
\end{abstract}

Conclusions: The major floristic differences between 1999 and 2013 were an increase in the number of upland plants and a decrease in wetland species. Although wetland indices were lower in 2013, the created wetland performed important ecosystem functions by providing habitats for wetland and upland plants, and the overall species diversity was high.

Keywords: Wetland creation, Ecological succession, Water depth, Wetland plants, Wetland index, Shannon diversity index, Species diversity

\section{Background}

Wetlands have various functions such as nutrient transportation, clean water supply, habitats for flora and fauna, sediment deposition, and buffers to climate changes (Hsu et al. 2011; Mitsch et al. 2012). Created wetlands are artificially designed and constructed to remove wastewater contaminants (Hsu et al. 2011) and serve not only as mitigation wetland to compensate for wetland habitat loss (Mitsch and Day 2006) but also as a pollutant treatment system for the removal of surface runoff (Mitsch et al. 2005; Vymazal 2013). These treatment systems are devised to mimic natural wetland systems by applying wetland plants, soils, and microorganisms to eliminate contaminants from

\footnotetext{
* Correspondence: ejlee@snu.ac.kr

'School of Biological Sciences, Seoul National University, Seoul 08826, South Korea

Full list of author information is available at the end of the article
}

wastewater effluents (Kivaisi 2001). In addition, assemblages and richness of waterfowl are influenced by characteristics of created wetlands (Choi et al. 2015). Thus, created wetlands attract much research interest.

Wetland plants are considered as either obligate or facultative wetland species, according to wetland delineations; are either partially or completely submerged in water during at least one stage of their growth; and must regularly encounter and tolerate anaerobic soils (Tiner 1991; Mitsch et al. 2012). Macrophytes are widely regarded as the main biological components of wetlands. They assimilate pollutants, act as catalysts for water purification (Hadad et al. 2006), and affect biodiversity in created wetlands (Hsu et al. 2011). Thus, due to their important roles in created wetlands, it is essential to investigate the composition and role of wetland plants.

(c) The Author(s). 2018 Open Access This article is distributed under the terms of the Creative Commons Attribution 4.0 International License (http://creativecommons.org/licenses/by/4.0/), which permits unrestricted use, distribution, and 
Hydrological conditions are probably the most important determinant of the type of wetland that can be established and the wetland processes that can be maintained (Mitsch and Gosselink 2000). In addition, the water regime is a crucial factor that determines the spatial-temporal diversity of wetland plants and also affects the richness and composition of plant communities (Makkay et al. 2008; Baart et al. 2010). Elements of the water regime include water depth, precipitation duration, rainfall frequency, and periodic cycle of wet and dry seasons (Rea and Ganf 1994). In particular, water depth is an important factor affecting species composition and plant community formation (Casanova and Brock 2000) and is a critical determinant of plant species diversity (Chen et al. 2006).

In wetlands, changes in floristic composition usually result from (1) the devastation of existing vegetation by pathogens, herbivores, or human activity; (2) changes in environmental conditions of habitats such as fluctuations in water depth or nutrient levels; (3) interactions among plants via symbiosis or competition; and (4) invasion of aggressive species (van der Valk 1981). Wetland succession involves floristic change as a function of time, and a spatial separation by water depth (Odland and del Moral 2002). Mitsch et al. (2012) concluded that plant richness in created wetlands undergoes the greatest increase in the first 5 years after creation. Meanwhile, Cole et al. (2013) found that plant communities should be monitored for longer than 5 years because changes remain ongoing, and long-term monitoring of created wetlands is needed to investigate trophic structure, nutrient flow, and the self-perpetuating processes of ecosystems (Moore et al. 1999).

Despite the importance of created wetlands, scientific understanding of their long-term succession is lacking (Mitsch et al. 2005). In South Korea, short-term studies (3-4 years) on created wetlands have been conducted, but longer-term studies for 10 years or longer are scarce (Kim and Myung 2008; Kim et al. 2011; Son et al. 2015). It is important to monitor the settlement patterns and changes in wetland plants after construction of wetlands. The purpose of this study was to compare the floristic changes in vegetation composition and wetland indices due to natural succession over a 15 -year period in a created wetland in South Korea.

\section{Methods}

\section{Site description}

This study was conducted at a created wetland of the Assum Ecological Systems INC. (36 $52^{\prime} 33.02^{\prime \prime} \mathrm{N}, 127^{\circ}$ $27^{\prime}$ 09.48' E) in Jincheon, South Korea, which was built for water purification tests in 1998 (Fig. 1). The length, width, and area of the wetland are $\sim 40 \mathrm{~m}, 70 \mathrm{~m}$, and $3000 \mathrm{~m}^{2}$, respectively, including four sub-wetland systems: a kidney-shaped wetland, a ditch, an ecological pond, and a square wetland.

The kidney-shaped wetland is in the northern part of the research site and is $\sim 9 \mathrm{~m}$ long by $1.5 \mathrm{~m}$ wide. The oval-shaped (almost circular) ecological pond has a diameter of $\sim 25 \mathrm{~m}$ and is located in the center of the research site. The curved ditch lies next to the kidneyshaped wetland, continues to the nearby ecological pond, and is $37 \mathrm{~m}$ long and $0.7 \mathrm{~m}$ wide. The square wetland consists of two square wetlands constructed out of concrete, located on the east side of the wetland, with a length of $10 \mathrm{~m}$. The water purification system, which uses wetland plants, requires the use of a test bed before application to the field, and these four sub-wetlands were established and operated for this purpose. However, water transfer/supply and maintenance of water depth ceased in the early 2000s, and the wetlands have experienced natural water depth fluctuations since then, resulting in natural vegetation changes.

\section{Vegetation survey and data analysis}

The first vegetation survey was conducted in October 1999, at 1 year after construction. We re-surveyed the vegetation in the created wetland 15 years later in May 2013. Species were monitored while walking through the research sites, and a list of plant species was recorded. Some species that were difficult to identify were collected and confirmed in the laboratory. The identification, naming, and classification of plant species were performed with reference to the Coloured Flora of Korea (Lee 2003), the Korean Plant Names Index (www.nature.go.kr), and the New Illustrations and Photographs of Naturalized Plants of Korea (Park 2009). Plants were categorized as obligate upland (OBU), facultative upland (FACU), facultative (FAC), facultative wetland (FACW), or obligate wetland (OBW) species following the field guide entitled "Categorizing Vascular Plant Species Occurring in Wetland Ecosystems of the Korean Peninsula" (Choung et al. 2012; Choung et al. 2015).

The wetland vegetation distribution in 1999 and 2013 was mapped using aerial images (http://map.daum.net/). After marking the boundaries of vegetation zones using aerial photographs, boundaries and types of vegetation were directly recorded. To investigate plant community structure, line-transect analysis was performed at the four sub-wetlands in 1999 and 2013. To reduce experimental error, two researchers carried out the surveys in both 1999 and 2013. The direction of transects in each wetland are shown in Fig. 1. Each transect included 910 quadrats, and the coverage of each species was not distorted where the vegetation changed suddenly; hence, the $0.5 \mathrm{~m} \times 0.5 \mathrm{~m}$ quadrat was placed on the right side of the transect. Water depth in each quadrat was measured and averaged using a meter stick. 


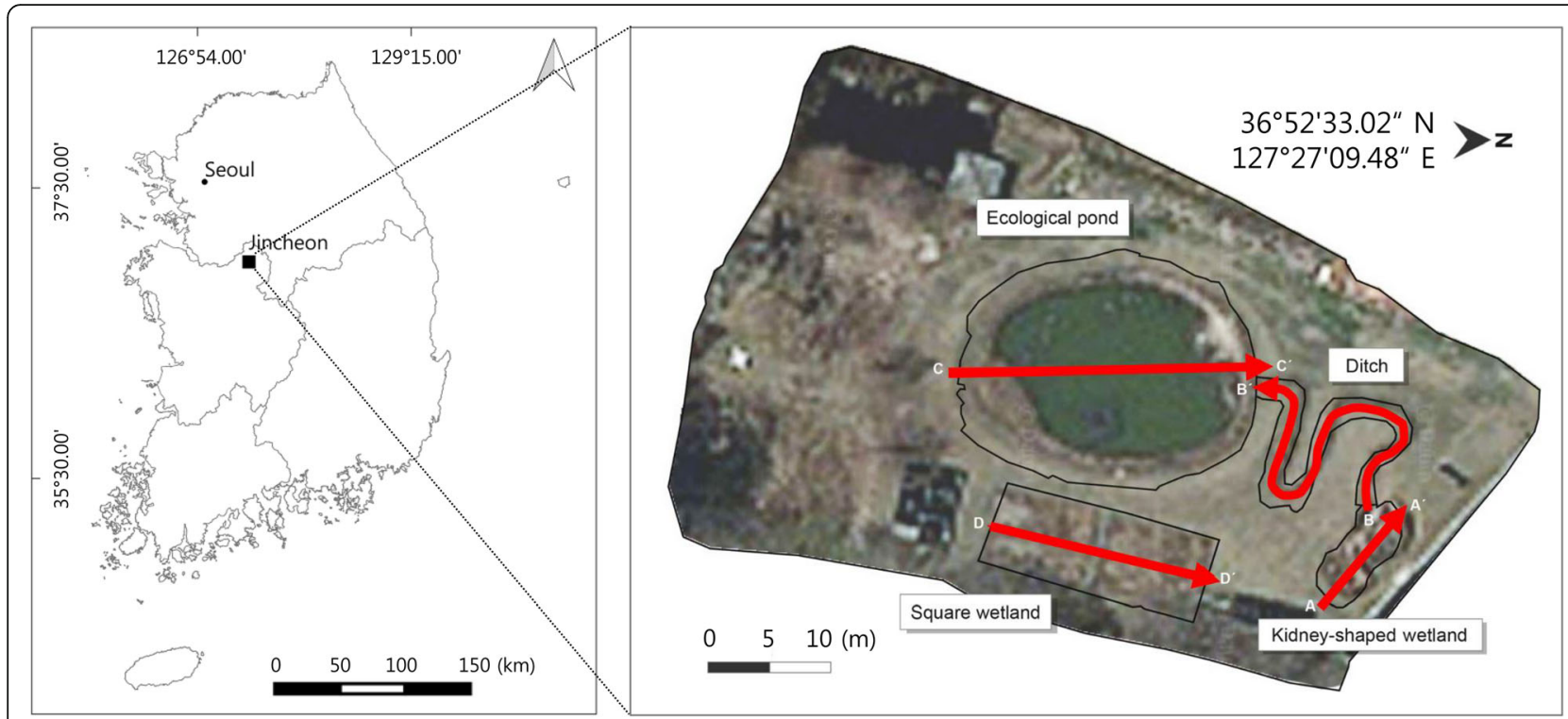

Fig. 1 Location of the created wetland in Jincheon, South Korea

The importance value (IV) was determined for each species (importance value $=$ relative cover + relative frequency) as described previously (Schlising and Sanders 1982), and diversity was calculated using the Shannon diversity index (Shannon and Weaver 1949). We evaluated changes in wetland index for the four sub-wetlands over time using the community type wetland index (CTWI) (Son et al. 2015; Chu et al. 2016), which can be effective for monitoring sites or comparing sites with environmental differences (Coles-Ritchie et al. 2007), using the following equation:

$$
\mathrm{CTWI}=\sum_{i=1}^{n} \mathrm{RImpi} * \mathrm{WIVi}
$$

where RImpi is the relative importance of species $i$ in the community type and WIVi (wetland indicator value) ranges from 1 to 100 for species $i$ based on the degree of wetness, $\mathrm{OBU}=1, \mathrm{FACU}=25, \mathrm{FAC}=50, \mathrm{FACW}=75$, and $\mathrm{OBW}=$ 100 (Coles-Ritchie et al. 2007; Choung et al. 2012).

To examine the relationships between wetland index, diversity, and water depth, regression analysis was conducted using seven datasets for the four sub-wetlands from 1999 and 2013. The dataset for the square wetland in 1999 was excluded because there were no plants; hence, we could not calculate wetland or diversity indices.

\section{Results}

\section{Surveyed flora}

A total of 18 species in 1999 belonging to 11 families and 13 genera were recorded at the four sub-wetlands. In the kidney-shaped wetland, only Typha angustifolia was planted in 1998, and all other plants were physically removed to control the water purification system. At 15 years after wetland construction, there were 21 families, 40 genera, and 50 species across the four sub-wetlands (Additional file 1). The ecological pond in 1999 and the ditch in 2013 contained the largest number of species (13 and 33, respectively).

\section{Vegetation distribution}

The wetland vegetation distribution in 1999 and 2013 was mapped using aerial images, focusing on dominant species (Fig. 2). The dominant species in 1999 was $T$. angustifolia at three of the four sub-wetlands with the exception of the square wetland where naturally established plants were eliminated for transplantation of seedlings for test beds. The most abundant species in 2013 were T. angustifolia (IV 0.464) and Phragmites australis (IV 0.255) at the kidney-shaped wetland, Calamagrostis epigeios (IV 0.157) and Carex dimorpholepis (IV 0.100) at the ditch, $P$. australis (IV 0.297) and T. angustifolia (IV 0.219) at the ecological pond, and Zizania latifolia (IV 0.115), Salix koriyanagi (IV 0.115), and Carex dispalata (IV 0.115) at the square wetland (Additional file 1). Thus, vegetation composition at the ditch and square wetland shifted prominently in 14 years, and new species were observed including Carex spp., Phragmites spp., and Salix spp. The size of floating vegetated islands at the ecological pond became smaller over time, with only Iris pseudacorus remaining.

\section{Species composition}

The proportion of wetland plants (FACW and OBW) decreased from 83\% in 1999 to 56\% in 2013 (Table 1). By contrast, the percentage of upland plants (FACU and 


\section{a}

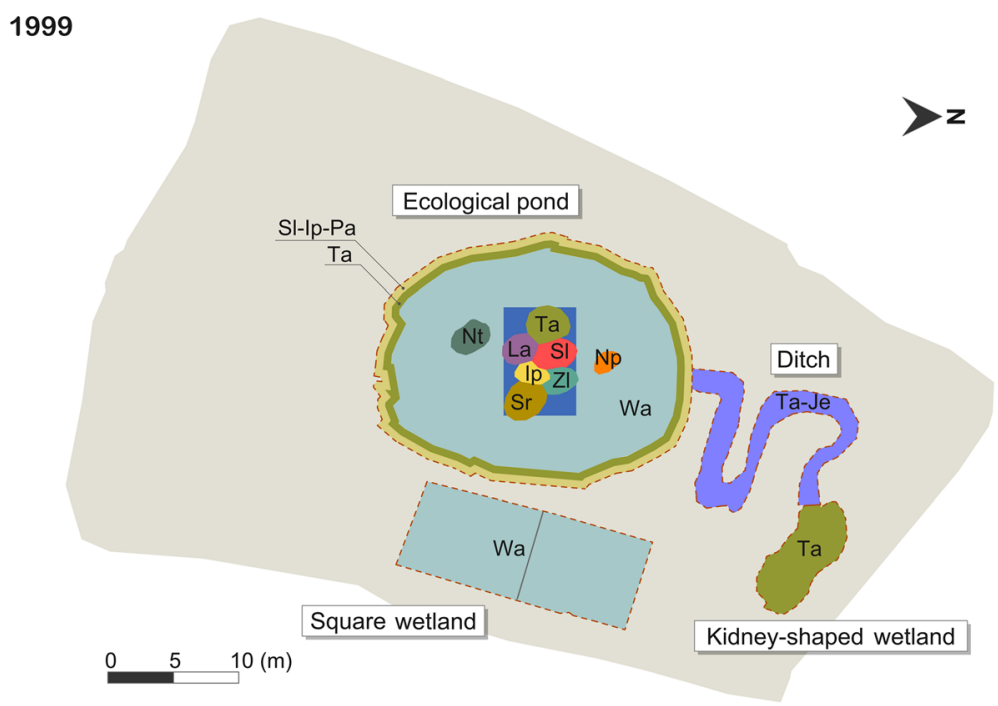

b

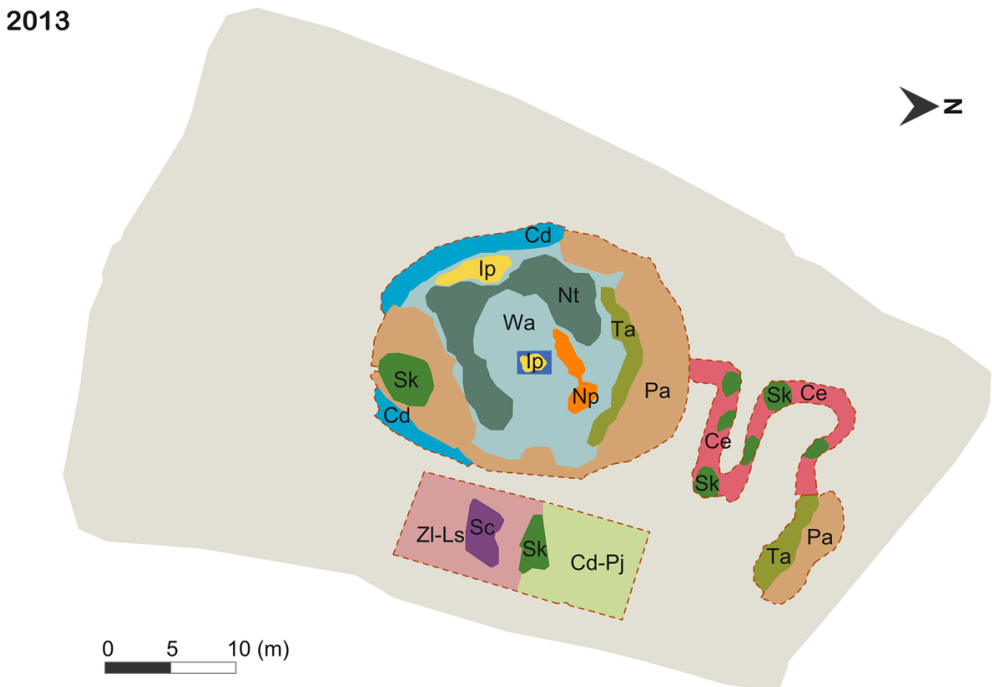

Fig. 2 Maps of vegetation distribution in 1999 and 2013. Cd, Carex dispalata; Ce, Calamagrostis epigeios; Ip; Iris pseudacorus; Je, Juncus effuusus var. decipiens; La, Lythrum anceps; Ls, Lythrum salicaria; Np, Nymphoides peltata; Nt, Nymphaea tetragona; Pa, Phragmites australis; Pj, Phragmites japonica; Sc, Salix chaenomeloides; Sk, Salix koriyanagi; SI, Schoenoplectus tabernaemontani; Sr, Scirpus radicans; Ta, Typha angustifolia; Wa, open water; Zl, Zizania latifolia

OBU) increased from 17 to $44 \%$. In this site, the number of non-native species increased from one to seven after 14 years, and the proportion of perennials decreased from 89 to $58 \%$ over this time although the total number of perennials increased by 13 species.

\section{Diversity and wetland indices}

Water depth at the four sub-wetlands in 2013 had decreased compared in 1999 (Table 2). At the ecological pond, the water depth was similar, and the kidneyshaped wetland showed the biggest decline after 14 years. Shannon diversity indices at all sub-wetlands increased as many species were introduced naturally over time. The ecological pond in 1999 displayed the highest diversity index (2.5), while the kidney-shape wetland and square wetland showed the lowest diversity indices (0). In 2013, the diversity index was highest at the ditch (3.2) and lowest at the kidney-shaped wetland (1.3). Wetland indices, excluding the square wetland, dropped compared with the early stages of wetland construction. The diversity index of the square wetland in 1999 was zero, but increased to 2.8 in 2013 as a result of the establishment of vegetation. The wetland index appeared to be positively correlated with water depth, while the Shannon diversity 
Table 1 Changes in plant species in a created wetland from 1999 to 2013 according to life cycle, origin, and plant type

\begin{tabular}{llll}
\hline Criterion & Category & Year & \\
\cline { 3 - 4 } & & 1999 & 2013 \\
\hline Life form & Annual & $1(5.5 \%)$ & $12(24 \%)$ \\
& Biennial & $1(5.5 \%)$ & $9(18 \%)$ \\
& Perennial & $16(89.0 \%)$ & $29(58 \%)$ \\
Total & & $18(100 \%)$ & $50(100 \%)$ \\
Origin & Native plant & $17(94 \%)$ & $43(86 \%)$ \\
& Non-native plant & $1(6 \%)$ & $7(14 \%)$ \\
Total & & $18(100 \%)$ & $50(100 \%)$ \\
Plant type & Obligate wetland (OBW) plant & $11(61 \%)$ & $13(26 \%)$ \\
& Facultative wetland (FACW) plant & $4(22 \%)$ & $15(30 \%)$ \\
& Facultative (FAC) plant & - & - \\
& Facultative upland (FACU) plant & - & $5(10 \%)$ \\
& Obligate upland (OBU) plant & $3(17 \%)$ & $17(34 \%)$ \\
Total & & $18(100 \%)$ & $50(100 \%)$ \\
\hline
\end{tabular}

index was unrelated to the wetland index or water depth (Fig. 3).

\section{Importance values of wetland plants}

At the kidney-shaped wetland, the importance value of OBW plants decreased over time, and FACW and OBU plants became established after 14 years (Fig. 4). In the early stages after wetland creation, OBW plants dominated at the ditch while FACW species were abundant during the latter period. Likewise, the dominance of OBW plants at the ecological pond has declined dramatically in 2013 compared with 1999. Nevertheless, the importance value of FACW increased slightly, and in 2013, FACW species were the most abundant at the square wetland, followed by OBW, OBU, and FACU.

\section{Discussion}

\section{Vegetation structure}

After four sub-wetlands were created in 1998, and the first vegetation survey was conducted in October 1999, to assess the establishment of artificially planted vegetation. The next vegetation monitoring was undertaken in May 2013, to investigate vegetation succession. The differences of seasons for vegetation monitoring between

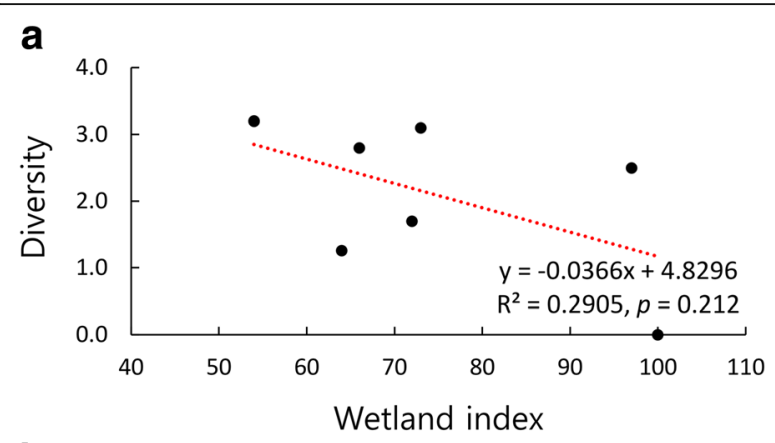

b

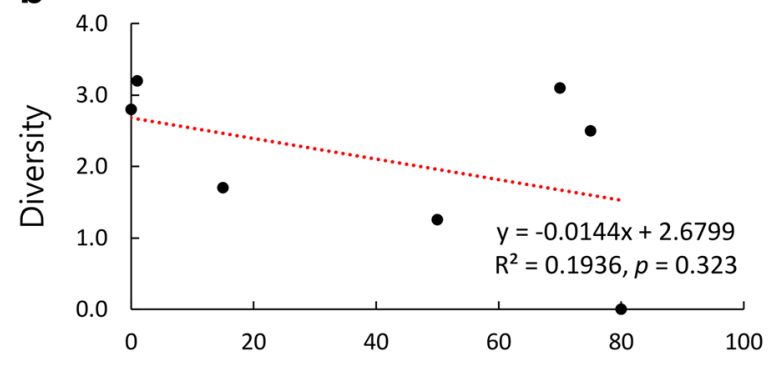

Water depth $(\mathrm{cm})$

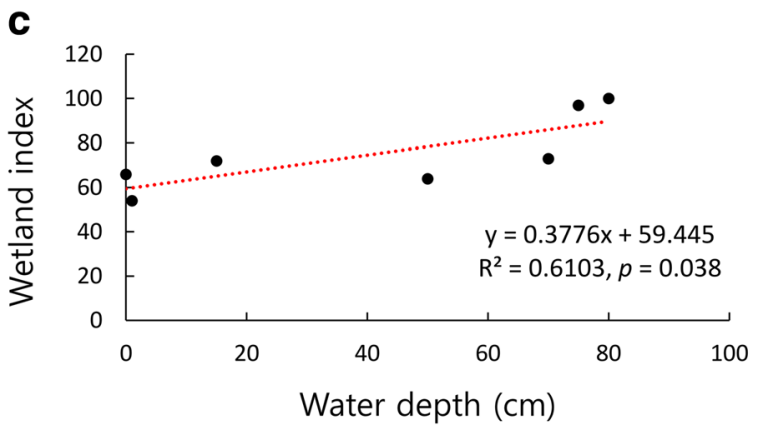

Fig. 3 Relationships a between wetland index and diversity, b water depth and diversity, and $\mathbf{c}$ water depth and wetland index at the four sub-wetlands

1999 and 2013 will not be a problem since in the early stages after wetland creation, all other plants excluding artificially planted species were eliminated to support the water quality improvement system, resulting in a similar vegetation composition maintained throughout the year in 1999 .

The kidney-shaped wetland was created to test the effects of $T$. angustifolia on water purification, and the

Table 2 Water depth, diversity index, and wetland index for four sub-wetlands in 1999 and 2013

\begin{tabular}{|c|c|c|c|c|c|c|}
\hline \multirow[t]{2}{*}{ Wetland type } & \multicolumn{2}{|c|}{ Water depth $(\mathrm{cm})$} & \multicolumn{2}{|c|}{ Shannon diversity index } & \multicolumn{2}{|c|}{ Wetland index } \\
\hline & 1999 & 2013 & 1999 & 2013 & 1999 & 2013 \\
\hline Kidney-shaped wetland & 80 & 50 & 0 & 1.3 & 100 & 83 \\
\hline Ditch & 15 & 1 & 1.7 & 3.2 & 72 & 54 \\
\hline Ecological pond & 75 & 70 & 2.5 & 3.1 & 97 & 73 \\
\hline Square wetland & 10 & 0 & 0 & 2.8 & 0 & 64 \\
\hline
\end{tabular}



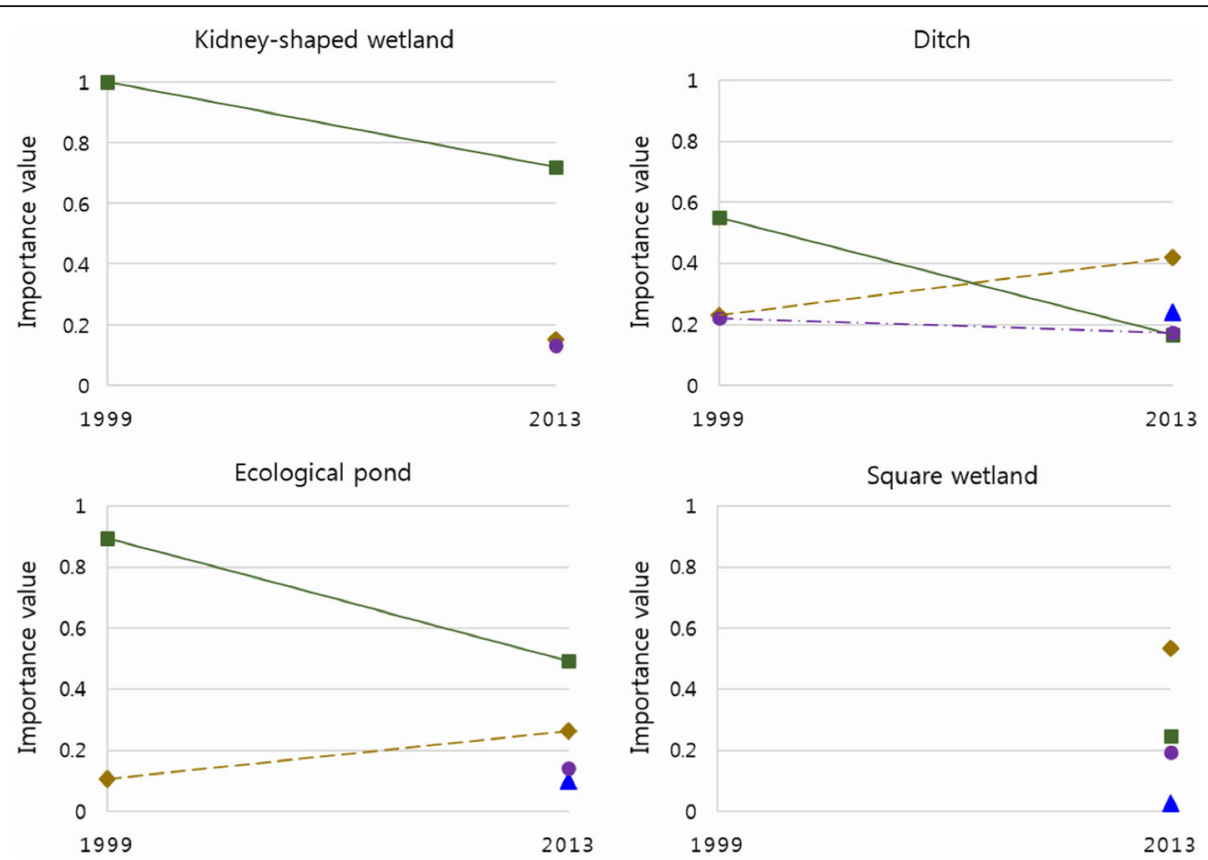

Fig. 4 Changes in importance value of wetland plants from 1999 to 2013 at the four sub-wetlands. $\mathbf{m}$, OBW (obligate wetland plant); $\bullet$ FACW (facultative wetland plant);

$\boldsymbol{\Delta}$, FACU (facultative upland plant); $\bullet$, OBU (obligate upland plant)

square wetland was constructed for transitory storage without plants. Therefore, during the early stages of wetland construction, the vegetation structure was simple and controlled, with only a few species present.

The vegetation composition at the ditch and square wetland shifted prominently over the 15 years, and new vegetation was observed such as Carex spp., Phragmites spp., and Salix spp. The size of floating vegetated islands at the ecological pond became smaller, with only Iris pseudacorus remaining. Scirpus radicans, Schoenoplectus tabernaemontani, Zizania latifolia, T. angustifolia, and Lythrum anceps had disappeared completely on the floating vegetated islands in 2013. However, it is difficult to determine whether some plants died naturally, were outcompeted, or managed because they have not been monitored to observe succession for 14 years.

In 2013, P. australis and T. angustifolia had spread widely at both the ecological pond and the kidneyshaped wetland compared with 1999 (Fig. 2). Phragmites australis is an aggressive colonizer of devastated sites and, once established, is difficult to eliminate (Havens et al. 1997). In addition, the settlement and vegetative growth of this species are favored by sedimentation and shallow water depth (Moore et al. 1999). It is known that T. angustifolia is dominant in shallow, organic sites with relatively intense competition (Wilson and Keddy 1991) and has a high competitive ability due to taller shoots and a higher standing crop in early summer (Weiner 1993). In 2013, in both the ditch and square wetland, Salix spp. were more dominant than in 1999. Vegetative perennials such as Salix spp. require a longer time to expand their canopy and must compete with faster growing herbs (Noon 1996). In oligotrophic to mesotrophic wetlands, Salix spp. are generally established later during succession (Toivonen and Lappalainen 1980), and their establishment ensures the continued decline of the groundwater level, which diminishes and eventually terminates the succession of plant communities in the order herbs, shrubs, and trees (Chen et al. 2006). After ceasing water supply, the water depth was almost 0 in the ditch and square wetland, where Salix spp. were dominant in 2013.

\section{Wetland plants, diversity indices, and water depth}

The main differences in species composition between the four sub-wetlands might be due to alterations in water depth and/or species planted following wetland construction. Water depth plays an important role in the growth of emergent species since they can endure anoxic soil conditions (van der Valk 1981). In addition, alterations in water depth influence light quality and quantity, and the ability of emergent plants to reach the surface (Casanova and Brock 2000). Many species without tolerance to water stress find it difficult to establish in deep water, and only certain plants, including OBW and FACW species, can fully adapt to a wet environment. As water depth decreases, upland plants (OBU and FACU) as well as wetland plants (OBW and FACW) can survive in different water depth ranges. 
Both OBW and FACW species are recognized as indicators of wetlands because these species are more often observed in wetlands than in non-wetlands (Tiner 1991). During vegetation succession, the proportion of OBW plants apparently declined, while FACW, FACU, and OBU species increased (Table 1, Fig. 4). The portion of wetland plants was reduced over time, but 56\% remained in 2013, demonstrating that the created wetland performed the function of habitats for wetland plants (Table 1). Under proper maintenance of water depth, created wetlands can greatly enhance biodiversity (Wiegleb et al. 2017).

At lower water depth, upland species are likely to establish in created wetlands, and diversity indices rise as a consequence. The changes in diversity indices observed herein suggest that this artificial ecosystem continued to develop and stabilize, in terms of terrestrialization, with sediment deposition and lower water depth (Table 2). Therefore, naturally introduced plant species exploit various ecological niches such as high and low ground, peripheral areas, and shallow and deep water (Pier et al. 2015).

Although the diversity index at the kidney-shaped wetland in 1999 was the lowest, the wetland index was the highest at this sub-wetland due to the abundance of OBW species. It is possible that the relationship between wetland index and diversity was not significant (Fig. 3). The high diversity suggests that both wetland plants and various facultative and upland plants became established in the created wetlands. Therefore, the wetland index of the kidney-shaped wetland, which was influenced by OBW plants, mainly Typha angustifolia, was higher in 1999 than any other sub-wetlands. Despite the high diversity, in 2013, the wetland index of the ditch, which contained no more than $1 \mathrm{~cm}$ of water, was low, mainly due to the abundance of upland species and fewer wetland species. Consequently, the relationship between wetland index and diversity index is not always positive.

\section{Conclusion}

Created wetlands play a significant role in water quality improvement and habitat provision for flora and fauna. In this study, we compared vegetation structure and water depth in a created wetland over a 15-year period after construction. Our results showed that total plant species increased from 18 in 1999 to 50 in 2013, but diversity indices in the four sub-wetlands decreased following natural succession. The proportion of wetland plants, including OBW and FACW species, decreased from 83 to $56 \%$, whereas values for upland plants, including OBU and FACU species, increased from 17 to $44 \%$.

Many natural wetland areas have been converted for urban development or infrastructure to optimize economic outputs (Ho and Richardson 2013), and this trend continues. Without extensive scientific knowledge, wetland rehabilitation may be inefficient and ineffective (OrtmannAjkai et al. 2018). To achieve greater biodiversity and wetland functions, heterogeneous environments must be maintained in created wetlands, with emphasis on water depth, margin slope, and substrate type (Vivian-Smith 1997; Shi et al. 2010).

In the present study, we could not collect data on wetland environmental parameters such as sedimentation, adjacent seed source, substrate, water quality, and periodical hydraulic cycle. In future studies, these factors should be integrated for a better understanding of the complexities of wetland succession. Additionally, seasonal species composition should be monitored, and the wetland should be considered not by itself, but in line with surrounding areas and conditions affecting wetland succession. Nevertheless, our current results provide baseline information on natural succession in created wetlands, and insight into maintaining wetland functions.

\section{Additional file}

Additional file 1: Table S1. Changes in vegetation and importance value for the four sub-wetlands from 1999 to 2013. (DOCX 38 kb)

\section{Abbreviations}

CTWI: Community type wetland index; FAC: Facultative; FACU: Facultative upland plant; FACW: Facultative wetland plant; OBU: Obligate upland; OBW: Obligate wetland

\section{Acknowledgements}

We especially thank Josu G. Alday (Universitat de Lleida) for providing helpful comments to this paper. We also thank the anonymous reviewers.

\section{Availability of data and materials}

The datasets are available from the corresponding author on reasonable request.

\section{Authors' contributions}

DS conducted the field survey and wrote the manuscript. $\mathrm{HL}$ and $\mathrm{KC}$ conducted the field survey and examined the manuscript. JB conducted the field survey and created the figures. OK participated in the design of the study. EL revised the manuscript. All authors read and approved the final manuscript.

Ethics approval and consent to participate Not applicable

\section{Competing interests}

The authors declare that they have no competing interests.

\section{Publisher's Note}

Springer Nature remains neutral with regard to jurisdictional claims in published maps and institutional affiliations.

\section{Author details}

'School of Biological Sciences, Seoul National University, Seoul 08826, South Korea. ${ }^{2}$ National Institute of Ecology, Seocheon 33657, South Korea.

${ }^{3}$ Department of Biological Sciences, Inha University, Incheon 22212, South

Korea. ${ }^{4}$ Assum Ecological System INC, Anyang 14056, South Korea. 
Received: 31 August 2018 Accepted: 30 October 2018

Published online: 14 November 2018

\section{References}

Baart I, Gschöpf C, Blaschke AP, Preiner S, Hein T. Prediction of potential macrophyte development in response to restoration measures in an urban riverine wetland. Aquat Bot. 2010;93:153-62.

Casanova MT, Brock MA. How do depth, duration and frequency of flooding influence the establishment of wetland plant communities? Plant Ecol. 2000;147:237-50

Chen Y-N, Zilliacus H, Li W-H, Zhang H-F, Chen Y-P. Ground-water level affects plant species diversity along the lower reaches of the Tarim river, Western China. J Arid Environ. 2006:66:231-46.

Choi J-Y, Jang J-D, Jeong K-S, Joo G-J. Effects of habitat conditions in created wetlands on sustaining wintering waterfowl in riverine plains, Nakdong River, South Korea. J. Ecol. Environ. 2015;38:343-52.

Choung Y, Lee WT, Cho K-H, Joo KY, Min BM, Hyun J-O, Lee KS. Categorizing vascular plant species occurring in wetland ecosystems of the Korean Peninsula. Chuncheon: Center for Aquatic Ecosystem Restoration; 2012.

Choung Y, Lee WT, Cho K-H, Joo KY, Min BM, Hyun J-O, Lee KS, Lee K, Seo A. Status of wetland vascular plant species in Korea. J Ecol Environ. 2015;38:541-4.

Chu YS, Cho H, Cho K-H. Response of vegetation to shoreline alternation in a large reservoir. Ecol Resil Infrast. 2016;3:143-51 (in Korean).

Cole CA, Urban CA, Russo P, Murray J, Hoyt D, Brooks RP. Herbaceous plant community composition in created wetlands over seven years in northern New York, USA. Stud Hist Gard Des. 2013;33:235-47.

Coles-Ritchie MC, Roberts DW, Kershner JL, Henderson RC. Use of a wetland index to evaluate changes in riparian vegetation after livestock exclusion. J Am Water Resour As. 2007:43:731-43.

Hadad HR, Maine MA, Bonetto CA. Macrophyte growth in a pilot-scale constructed wetland for industrial wastewater treatment. Chemosphere. 2006;63:1744-53

Havens KJ, Priest I, Walter I, Berquist H. Investigation and long-term monitoring of Phragmites australis within Virginia's constructed wetland sites. Environ Manag. 1997;21:599-605.

Ho M, Richardson CJ. A five year study of floristic succession in a restored urban wetland. Ecol Eng. 2013:61:511-8.

Hsu C-B, Hsieh H-L, Yang L, Wu S-H, Chang J-S, Hsiao S-C, Su H-C, Yeh C-H, Ho Y$\mathrm{S}$, Lin $\mathrm{H}$-J. Biodiversity of constructed wetlands for wastewater treatment. Ecol Eng. 2011;37:1533-45.

Kim C-H, Choi Y-E, Kim J-W, Myung H, Lee S-I. 3-year change of vegetation and life form at the man-made wetland in Sinpyeoncheon city. Korean J Environ Ecol. 2011:25:57-64 (in Korean).

Kim C-H, Myung H. A 4-year follow-up survey of flora at the human-made wetlands along Boknaecheon of Juam Lake. J Korea Soc Environ Restor Technol. 2008;11:25-37 (in Korean).

Kivaisi AK. The potential for constructed wetlands for wastewater treatment and reuse in developing countries: a review. Ecol Eng. 2001;16:545-60.

Lee TB. Coloured flora of Korea. Seoul: Hyang Mun Sa; 2003. (in Korean)

Makkay K, Pick FR, Gillespie L. Predicting diversity versus community composition of aquatic plants at the river scale. Aquat Bot. 2008;88:338-46.

Mitsch WJ, Day JW. Restoration of wetlands in the Mississippi-Ohio-Missouri (MOM) River Basin: experience and needed research. Ecol Eng. 2006;26:55-69.

Mitsch WJ, Gosselink J. Wetlands. New York: John Wiley \& Sons; 2000

Mitsch WJ, Zhang L, Anderson CJ, Altor AE, Hernández ME. Creating riverine wetlands: ecological succession, nutrient retention, and pulsing effects. Ecol Eng. 2005;25:510-27.

Mitsch WJ, Zhang L, Stefanik KC, Nahlik AM, Anderson CJ, Bernal B, Hernandez M, Song K. Creating wetlands: primary succession, water quality changes, and self-design over 15 years. Bioscience. 2012;62:237-50.

Moore $\mathrm{HH}$, Niering WA, Marsicano LJ, Dowdell M. Vegetation change in created emergent wetlands (1988-1996) in Connecticut (USA). Wetl Ecol Manag. 1999;7:177-91.

Noon KF. A model of created wetland primary succession. Landscape Urban Plann. 1996:34:97-123.

Odland A, del Moral R. Thirteen years of wetland vegetation succession following a permanent drawdown, Myrkdalen Lake, Norway. Plant Ecol. 2002;162:185-98.

Ortmann-Ajkai A, Csicsek G, Hollós R, Magyaros V, Wágner L, Lóczy D. Twentyyears' changes of wetland vegetation: effects of floodplain-level threats. Wetlands. 2018;38:591-604.
Park SH. New illustrations and photographs of naturalized plants of Korea. Seoul: Ilchokak Publishing Co. Ltd.; 2009. (in Korean)

Pier B, Dresser B, Lee J, Boylen C, Nierzwicki-Bauer S. Ecological analysis before and after planting in a constructed wetland in the Adirondacks. Wetlands. 2015:35:611-24.

Rea N, Ganf GG. How emergent plants experience water regime in a Mediterranean-type wetland. Aquat Bot. 1994;49:117-36.

Schlising RA, Sanders EL. Quantitative analysis of vegetation at the Richvale vernal pools, California. Am J Bot. 1982:734-42.

Shannon CE, Weaver W. The mathematical theory of communication. Illinois: University of Illinois press; 1949

Shi J, Ma K, Wang J, Zhao J, He K. Vascular plant species richness on wetland remnants is determined by both area and habitat heterogeneity. Biodivers Conserv. 2010;19:1279-95.

Son D, Lee H, Lee EJ, Cho K-H, Kwon D. Flora and vegetation structure in a 15year-old artificial wetland. Ecol Resil Infrast. 2015;2:54-63 (in Korean).

Tiner RW. The concept of a hydrophyte for wetland identification. Bioscience. 1991;41:236-47.

Toivonen $\mathrm{H}$, Lappalainen T. Ecology and production of aquatic macrophytes in the oligotrophic, mesohumic lake Suomunjärvi, eastern Finland. Ann Bot Fennici. 1980;17:69-85.

Van der Valk A. Succession in wetlands: a Gleasonian approach. Ecology. 1981;62: 688-96.

Vivian-Smith G. Microtopographic heterogeneity and floristic diversity in experimental wetland communities. J Ecol. 1997;85:71-82.

Vymazal J. Plants in constructed, restored and created wetlands. Ecol Eng. 2013;61:501-4.

Weiner SE. Long-term competitive displacement of Typha latifolia by Typha angustifolia in a eutrophic lake. Oecologia. 1993;94:451-6.

Wiegleb G, Dahms H-U, Byeon W, Choi G. To what extent can constructed wetlands enhance biodiversity? Int J Environ Sci Dev. 2017;8:561-9.

Wilson SD, Keddy PA. Competition, survivorship and growth in macrophyte communities. Freshw Biol. 1991:25:331-7.

\section{Ready to submit your research? Choose BMC and benefit from:}

- fast, convenient online submission

- thorough peer review by experienced researchers in your field

- rapid publication on acceptance

- support for research data, including large and complex data types

- gold Open Access which fosters wider collaboration and increased citations

- maximum visibility for your research: over $100 \mathrm{M}$ website views per year

At $\mathrm{BMC}$, research is always in progress.

Learn more biomedcentral.com/submissions 